\title{
Needs, aggravation, and degree of burnout in informal care providers of patients with chronic CVD
}

Elżbieta Szlenk-Czyczerska ( $\sim$ ela6035@onet.pl )

Panstwowa Medyczna Wyzsza Szkola Zawodowa w Opolu https://orcid.org/0000-0002-8145-6768

\section{Marika Guzik}

Medical and Diagnostic Centre (MDC), Siedlce, Poland

\section{Dorota Emilia Bielska}

Department of Family Medicine, Medical University of Bialystok, Poland

\section{Anna Ławnik}

Pope John Paul State School in Biala Podlaska, Faculty of Health Sciences and Social Sciences, Poland

\section{Piotr Polański}

Family physician's, Non-Public Healthcare Center, Mieroszow, Poland

\section{Donata Kurpas}

Department of Family Medicine, Wroclaw Medical University, Poland

\section{Research article}

Keywords: informal caretaker, met and unmet needs, growing burnout

Posted Date: April 29th, 2020

DOI: https://doi.org/10.21203/rs.3.rs-22861/v1

License: (c) (i) This work is licensed under a Creative Commons Attribution 4.0 International License.

Read Full License 


\section{Abstract \\ Background.}

The growing number of patients with chronic cardiovascular disease (CVD) has created an increased demand for homecare. Therefore, it is necessary to analyze the burden of homecare on caregivers, and gain insight into their biopsychosocial situations. By identifying groups of caregivers that experience significant levels of stress and burnout, guardian education (i.e. specialized and supportive training) and practical support can be specifically directed towards these groups. This study aimed to answer two main questions with respect to home carers for people with CVD: 1) Are the needs of home carers being met (and at what level), and what is the severity of burnout of home carers? and 2) What sociodemographic variables of home carers are related to unmet needs and severity of burnout?

\section{Methods.}

This study reports on 161 informal home care providers of patients with CVDs. The research was conducted in the homes of patients, using the Camberwell Assessment of Need Short Appraisal Schedule (CANSAS), the Maslach Burnout Inventory (MBI), and a structured interview questionnaire developed by the authors. Spearman's rank correlation coefficient test and logistic regression were used for analyses.

\section{Results.}

The majority of the participants were female $(70.2 \% ; n=113)$. We found that younger care providers were less likely to report unmet needs $(p=0.011)$, and less likely to report burnout as measured by the MBI Emotional Exhaustion $(p=0.010)$ and Depersonalization $(p=0.009)$ subscales. Care providers with primary education were more likely to report burnout on the MBI Depersonalization subscale $(p=0.028)$. In addition, care providers who worked more often reported higher levels of met needs $(p=0.022)$, and burnout as measured on the MBI Depersonalization $(p=0.005)$ and Emotional Exhaustion $(p=0.018)$ subscales. Subjects residing in urban areas were more likely to report unmet needs $(p=0.007)$, and were also more likely to report burnout as measured on the MBI Emotional Exhaustion $(p=0.006)$ subscale.

\section{Conclusion.}

Older care providers who are unemployed and reside in cities and unemployed should be targeted with directed programmes to determine the category of unmet needs, and for personalized support. Care providers with these demographic characteristics should be targeted for occupational burnout prevention programmes.

\section{Background}


The rising prevalence of cardiovascular diseases (CVD) has become a major health concern around the world. The impact of CVDs should not only be considered from a medical perspective, but also be evaluated in terms of its social and economic impact. It appears that the most important factor in the increasing number of people being diagnosed with CVD is an aging population, as the incidence of these diseases increases significantly with age [1-3]. In the USA, approximately $50 \%$ of people over the age of 80 have clinical symptoms of atherosclerosis and/or heart failure [4].

Health deterioration with age causes limitations in everyday life, the need for external support and increased intensity of using health care services - these include care, treatment and rehabilitation [5]. It is therefore reasonable to search for activities and support systems, both medical and environmental, which will help to maintain optimal health and improve the quality of life of patients with chronic CVD. Analysis of burden, and increasing our knowledge about the biopsychosocial status of health carers for people with CVD will make it possible to determine which carers are the most burdened, thus allowing practical support to be targeted towards specific groups of carers.

The care of chronically ill and/or elderly patients is a priority in most countries, and a patient's home is considered to be the preferable location for providing care [6]. As the number of elderly and/or chronically ill individuals continues to grow globally, the role of 'informal care providers' becomes more relevant. Informal care providers are most often family members or friends who work for free and provide support to those in need [7].

In Europe, there are an estimated 100 million informal care providers. The estimated care contribution of these providers exceeds the financial expenses of formal nursing care. In England and Wales alone, an estimated 950000 residents over the age of 65 are thought to be informal care providers, and $65 \%$ of these individuals (aged 60-94) experience long term health problems or disabilities themselves [8].

In Poland, it is clear that the majority of chronically ill and/or disabled individuals in need receive help from informal family care providers [9]. According to the Central Office of Statistics, three out of four care providers look after their own family members, are male, and reside in urban areas. In contrast, females and those who reside in cities provide support to patients who family members, as well as, individuals outside of their family. The latter feature applies to every fifth caregiver. A very small group of individuals $(16 \%)$ was found to provide care to individuals both in and outside of their family, at least once per week [10].

Older adults living with chronic diseases often rely on the support of informal carers who assist them in their daily activities [11]. Research clearly shows that informal care providers play a substantial role in homecare [12].

Despite increasing awareness of the key role of care providers, there is a lack of knowledge on how to support them. Care for older adults, without adequate support, can negatively affect a person's financial, emotional and mental well-being [13]. Restrictions in both private and professional spheres, as well as health problems among caregivers (often due to a lack of system support) are reasons for the failure of 
models of care for chronically ill people, especially at home. Further, the support of elderly, chronically ill, and/or disabled informal care providers requires more attention and recognition. There is a strong need for access to different forms of support services that care providers might be able to choose from $[14,15]$.

One previous study among care providers of patients recovering from a cerebrovascular incident examined the impact of caregiver support on quality of life and perceived burden [15]. This study showed that, if not supported by health services, care providers showed a deterioration in their own health. Further, females and subjects under 60 were most frequently exposed to stress. Previous research has also demonstrated that care providers suffer more mental distress and the overload is more severe when they do not have an additional assistant, or when they have their own health issues [16]. Current recommendations for the homecare of elderly and/or chronically ill patients should be sustained; however, the needs, expectations, and health condition of care providers should be taken into much greater consideration [12].

In Poland, the reality is that most chronically ill patients and those in the end-of-life phase remain at home and health care is provided by family members and other informal care providers. There is, however, a lack information regarding these informal forms of care [12].

In particular, there is a paucity of data in the literature regarding the relationship between sociodemographic factors and the needs and severity of burnout in care of CVD patients.

\section{Present Study}

Considering the above, the purpose of this study was to analyze the level of needs and severity of burnout in home caregivers for people with CVD, and to determine what sociodemographic variables of home carers are associated with these factors. Results of this study may help to identify the individuals and families who need support in taking care of patients who are not self-reliant patients. Results may also inform the creation of evaluation tools to assess the quality of care, and the needs and expectations of care, from somatic, mental, social, and environmental perspectives.

\section{Methods}

\section{Study Design}

This study is a cross-sectional observational study. This study is part of a broader study to identify indicators that determine the effectiveness of home care for patients with chronic CVD, and to identify variables that determine effective support systems for their home carers. The study involved 350 patients with CVD. In order to define indicators specific to home care, 193 patients remained in the home environment under the care of primary care family nurses, while 157 patients went out to see their GP for follow-up visits. The study also included caregivers of patients under home care of primary care family 
nurses. The study involved 161 caregivers. This article presents a partial analysis of the results of this study on the level of needs and severity of burnout in home care for people with CVD.

\section{Setting}

The study was conducted in Polish CVD patients and their informal caregivers. These patients received home care from a family nurse working in basic health care in the Opolskie, Dolnośląskie, Mazowieckie, Lubelskie and Podlaskie provinces. Eight primary care institutions took part in the study. Patients and caregivers were encouraged to take part in the study by a family nurse during planned home visits. Respondents completed questionnaires in their home environment. Patients and caregivers were provided with one set of questionnaires each, and nurses completed an additional questionnaire concerning the patient (i.e. paired questionnaires with respect to the same patient). Data was collected from March 2016 to January 2017.

\section{Participants}

180 informal tutors (i.e. caregivers) were invited to participate in the survey, but the final sample of participants was determined on the basis of their temporal availability. Finally, 161 people took part in the survey. The criteria for inclusion in the study were as follows: 18 years of age, and taking care of a patient with chronic CVD under home care at least 12 months before the study. The exclusion criteria (disqualification as determined by the family nurse) were cognitive disorders and other intensified mental disorders, and/or other difficulties preventing active participation in the study (e.g., visual disorders, a patient not speaking Polish as the first language, etc.).

\section{Instruments And Data Collection}

In this study, 36 variables were analysed, ranging from sociodemographic variables (e.g., sex, age, marital status, education, place of residence, the degree of relation to the patient, employment, period of care given, etc.), as well as variables relating to the degree of burden experienced by home care providers.

Needs of informal home care providers of CVD patients were assessed with the CANSAS. The CANSAS consists of 24 questions that cover 22 different problem areas related to the somatically and chronically ill. Of note, the questionnaire is for individuals who do not display severe mental disorders. Participants rate the different needs as either unmet (coded 0 ) or met (coded 1 ). We computed the total number of needs $(\mathrm{N})$ that participants reported as unmet and met. Of note, missing data (i.e., participant nonresponses) were omitted from analysis. In addition, we computed the Camberwell index, which was calculated according to the formula 1-M/N. The consistency for the CANSAS questionnaire (i.e., Cronbach's alpha) is 0.82 [17]. 
The present study also administered the Maslach Burnout Inventory (MBI), which was developed by Maslach and Jackson in 1981. The MBI provide insight into three components of the burnout syndrome, which are divided into subscales, namely: (1) emotional exhaustion (EE), (2) depersonalization (DE), and (3) a decreased level of personal achievement (PA). The MBI questionnaire contains 22 test items that are divided into the three burnout subscales, listed above. Nine of the 22 items correspond to the emotional exhaustion subscale, five items to the DE subscale, and eight items correspond to decreased PA. The test items in emotional exhaustion and depersonalization subscales are formulated negatively, whereas items from the decreased PA subscale are positive. Each question is structured affirmatively and relates to the attitude and feelings that a participant may experience and rates on a 7-point scale (where 0 means never, and 6 means every day). The results are calculated separately for each subscale. A high level of burnout is characterized by high scores on the EE and DE subscales and low scores on the decreased level of PA subscale [18]. The MBI questionnaire is frequently applied in research on occupational burnout. According to Maslach and Jackson, the MBI can be used in professions that require contacting other people. It was, however, indicated, that after the adaptation, the questionnaire might be applied more broadly by changing some words, but the meaning of the scale remains the same [19].

To assess the sociodemographic aspects of the care providers, an interview questionnaire was administered that assessed sex, age, marital status, education, place of residence, degree of relation to the patient, employment, and the period of care provided.

\section{Study Size}

161 informal care providers accepted the invitation to participate and ultimately completed the study. Of note, there were missing data from care providers for the following variables: age, marital status, employment, and period of caretaking. Thus, the numbers provided in the columns do not sum up to 161 . Of note, for three cases, a non-family caregiver was both a neighbour and an informal partner.

\section{Ethics Approval And Consent To Participate}

The study was approved by the Bioethical Commission at Medical University in Wroclaw (No KB -86/2016). Participation in the study was voluntary and anonymous. All participants were informed about the study aims, methods, and the ability to withdrawal participation at any stage of the examination.

\section{Statistical Methods}

The results of the study were subject to statistical analysis with the use of $\mathrm{R}$ statistical package (version 3.4.0).

For the quantitative variables, the arithmetic mean, standard deviation, first quartile (Q.25\%), second quartile (Q.50\%) of the median, third quartile (Q.75\%), minimum, and maximum were calculated. For 
qualitative variables, frequency (i.e., percent) was determined. The Shapiro-Wilk test showed that only two qualitative variables (i.e., age, decreased level of PA on the MBI) showed a normal distribution. The other included variables diverged from the normal distribution. Chi-square test was used to assess the qualitative variables.

The relationship between sociodemographic variables and the assessment of needs and severity of burnout was analysed using Spearman's rank correlation coefficient, which does not require normal distribution of the variables. The null hypothesis $(\mathrm{HO})$ is tested wherein the Spearman's rank correlation coefficient equals 0 . The alternative hypothesis that the correlation coefficient differs from 0 . The null hypothesis $(\mathrm{H} 0)$ was rejected if the $p$-value was $<0.05(\mathrm{a}=0.05)$.

Logistic regression analysis was used to describe the relationship between demographic data of care providers and their needs and severity of burnout, via an odds ratio. Separate regression analyses were carried out for each of the following dichotomous outcome variables:

- unmet needs: 0 , if median scores on the Camberwell $\leq 0.875 ; 1$, if Camberwell $>875$,

- EE: 0 , if median scores on the MBI-EE $\leq 20 ; 1$ if MBI-EE $>20$,

- DE: 0 , if median scores on the MBI-D $\leq 6 ; 1$, if MBI-D > 6,

- decreased level of PA: 0, if MBI-PA $\leq 29$ (median); 1 if MBI-PA > 29.

The variables used in logistic regression analysis models were selected from the following 29 variables (Table 1): 
Table 1

Descriptive variables for logistic regression analysis models

\begin{tabular}{|c|c|c|}
\hline & Variables & Coding \\
\hline \multirow[t]{2}{*}{$\mathrm{x} 1$} & Gender & $1-$ Women \\
\hline & & $2-$ Men \\
\hline$x 2$ & Age (in years) & Number of years \\
\hline \multirow[t]{4}{*}{$x 3$} & Marital status & $1-$ Single \\
\hline & & 2 - Married \\
\hline & & 3 - Widowed \\
\hline & & 4 - Divorced \\
\hline \multirow[t]{4}{*}{$x 4$} & Place of residence & $1-$ Big city $<100$ thousand inhabitants \\
\hline & & 2 - Middle town from $20-100$ thousand inhabitants \\
\hline & & $3-$ Town small $>20$ thousand inhabitants \\
\hline & & 4 - Village \\
\hline \multirow[t]{7}{*}{$x 5$} & Education & 1 - Primary \\
\hline & & 2 - Vocational \\
\hline & & 3 - Secondary without Matura Exam \\
\hline & & 4 - Secondary with Matura Exam \\
\hline & & 5 - Post-secondary \\
\hline & & $6-B A$ \\
\hline & & $7-M A$ \\
\hline \multirow[t]{6}{*}{$x 6$} & Family-related carer & 1 - Wife/husband \\
\hline & & 2 - Brother/sister \\
\hline & & 3 - Mother/father \\
\hline & & 4 - Uncle/aunt \\
\hline & & $5-$ Cousin \\
\hline & & 6 - Other \\
\hline \multirow[t]{3}{*}{$x 7$} & Non-family carer & 1 - Neighbour \\
\hline & & 2 - Informal partner \\
\hline & & 3 - Other \\
\hline
\end{tabular}




\begin{tabular}{|lll|}
\hline \multicolumn{2}{|c|}{ Variables } & Coding \\
\hline x8 Employment & 1 - Full time \\
& $2-$ Part-time \\
& $3-$ Sick leave-child care \\
& $4-$ Sick leave \\
& $5-$ Unemployment benefit \\
& $6-$ Unemployment \\
& & Number of years \\
\hline
\end{tabular}

Next, for each explained variable, a separate logistic regression analysis, for at least 9 different explanatory variables, was carried out to examine all possible models. For further analysis, only specific models that demonstrated significance were chosen. All variables in the model had to be statistically significant and included the largest number of explanatory variables, in the smallest number of models. Using the models selected, the odds ratio for the events examined were calculated and conclusions formulated on their basis. This approach did not require the use of model-matching procedures. The significance level was established at 0.05 .

\section{Results}

\section{Participants}

Most of the care providers for CVD patients were women $(70.2 \% ; n=113)$, and the median age was 55 years (min.-max.: 17.00-95.00; IQR: 42.50-55.00-64.00). The majority of care providers were married $(65.6 \% ; n=105)$, highly-educated $(28.6 \% ; n=46)$ or with secondary education $(23.6 \% ; n=38)$, and resided in cities $(58.4 \% ; n=94)$. Homecare was provided primarily by the patients' parents $(42.3 \% ; n=63)$, followed by spouses $(28.2 \% ; n=42)$ and other relatives $(18.1 \% ; n=27) .48 .4 \%(n=76)$ of care providers were employed full-time, and $36.9 \%(n=58)$ were currently unemployed. The median period of care given was 4 years (min.-max.: 1.00-51.00; IQR: 2.00-10.00, p<0.001) (see Table 2). 
Table 2

Sociodemographic data of care providers*

\begin{tabular}{|c|c|c|c|}
\hline \multicolumn{2}{|l|}{ Variable $(n=161)$} & \multirow{2}{*}{$\begin{array}{l}n \\
113\end{array}$} & \multirow{2}{*}{$\begin{array}{l}\% \\
70.2\end{array}$} \\
\hline Gender & women & & \\
\hline & men & 48 & 29.8 \\
\hline \multirow{6}{*}{$\begin{array}{l}\text { Age } \\
\text { (in years) }\end{array}$} & n & \multicolumn{2}{|l|}{159} \\
\hline & mean $(\mathrm{M})$ & \multicolumn{2}{|c|}{54.33} \\
\hline & standard deviation (SD) & \multicolumn{2}{|c|}{15.36} \\
\hline & median (Me) & \multicolumn{2}{|c|}{55.00} \\
\hline & Q.25\%-Q.50\%-Q.75\% & \multicolumn{2}{|c|}{$42.50-55.00-64.00$} \\
\hline & $\min .-\max$ & \multicolumn{2}{|c|}{$17.00-95.00$} \\
\hline \multirow[t]{8}{*}{ Education } & primary & 16 & 9.9 \\
\hline & vocational & 37 & 23 \\
\hline & secondary without Matura Exam & 7 & 4.3 \\
\hline & secondary with Matura Exam & 38 & 23.6 \\
\hline & post-secondary & 11 & 6.8 \\
\hline & BA & 6 & 3.7 \\
\hline & MA & 46 & 28.6 \\
\hline & total & 161 & 100 \\
\hline \multirow[t]{3}{*}{ Place of residence } & urban & 94 & 58.4 \\
\hline & rural & 67 & 41.6 \\
\hline & total & 161 & 100 \\
\hline \multirow[t]{5}{*}{ Marital status } & single & 31 & 19.4 \\
\hline & married & 105 & 65.6 \\
\hline & widowed & 15 & 9.4 \\
\hline & divorced & 9 & 5.6 \\
\hline & total & 160 & 100 \\
\hline Family-related care provider & wife/husband & 42 & 28.2 \\
\hline $\begin{array}{l}\text { Legend: } n \text {-group quantity, } \% \\
\text { Me - median; } Q .75 \% \text { - third } \\
\text { not sum up to } 161 \text { due to mi }\end{array}$ & $\begin{array}{l}\text { entage; M - mean; SD - standard } \\
\text { e; Min. - minimum; Max. - maxim } \\
\text { lata. }\end{array}$ & $\begin{array}{l}\text { on; Q.2 } \\
\text { he figu }\end{array}$ & $\begin{array}{l}\text { rst quartile; } \\
\text { column n do }\end{array}$ \\
\hline
\end{tabular}




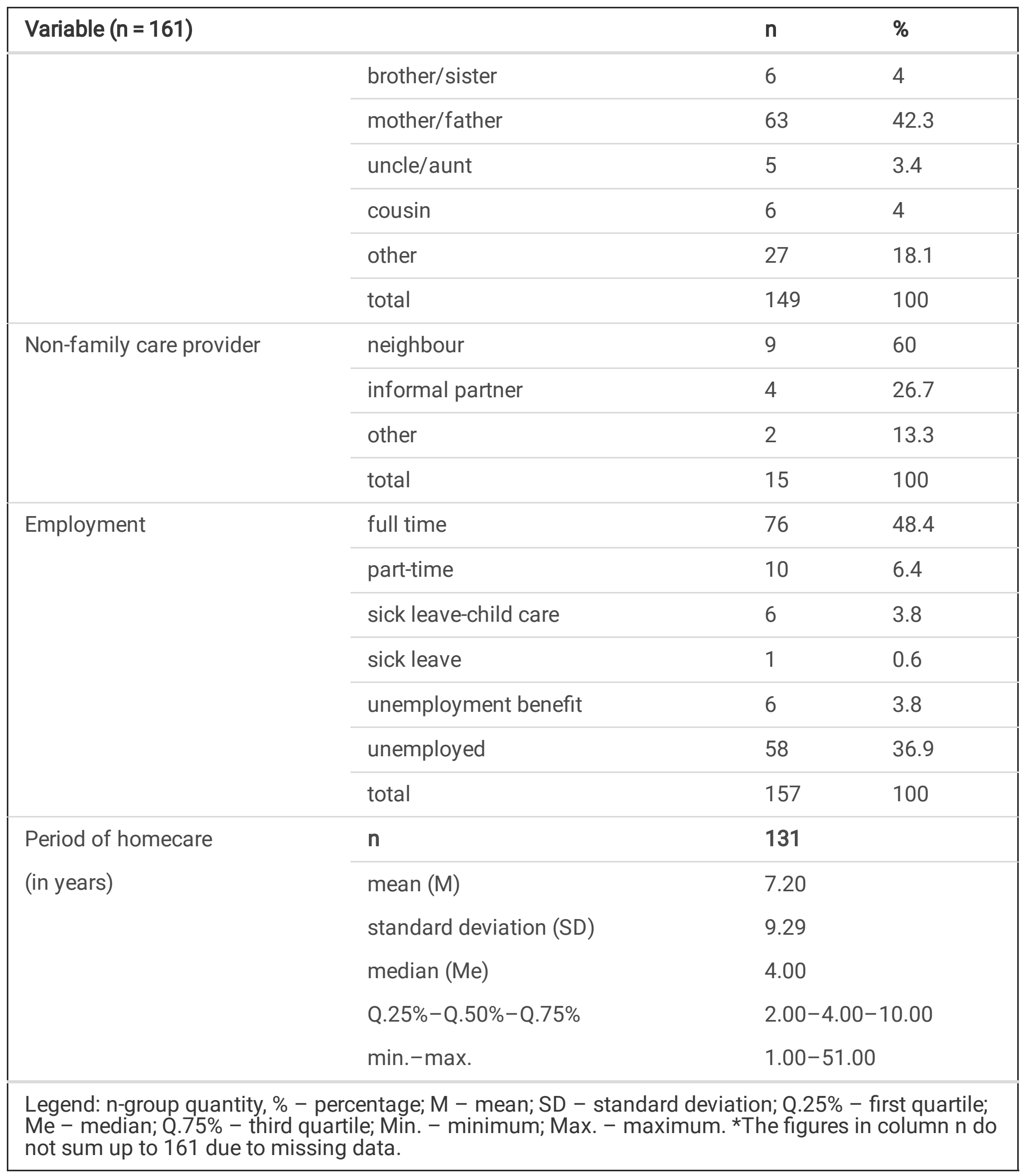

\section{Assessment of the level of needs and severity of burnout among care providers}


The calculated Camberwell index is 0.88 (min.-max.: 0.44-1). The median score on the emotional exhaustion subscale is 20 (min.-max.: $0-50$ ); the median DE score is 6 (min.-max.: 0-24), and the mean decreased level of $P A$ is $29.07 \pm 8.43$. These data suggest a moderate level of $E E$, a low level of $D E$, and high level of PA (see Table 3).

Table 3

Assessment of the level of needs and burnout among care providers

\begin{tabular}{|c|c|c|c|c|c|c|c|c|c|}
\hline Variable & $\mathbf{n}$ & $M$ & SD & $Q, 25 \%$ & $\mathrm{Me}$ & Q,75\% & Min. & Max. & $p$ \\
\hline Camberwell Index & 161 & 0.83 & 0.13 & 0.76 & 0.88 & 0.94 & 0.44 & 1.00 & $\hat{0}_{0.001}$ \\
\hline $\begin{array}{l}\text { Emotional exhaustion } \\
(\mathrm{EE})\end{array}$ & 154 & 20.28 & 12.52 & 10.00 & 20.00 & 28.00 & 0.00 & 50.00 & 0.002 \\
\hline $\begin{array}{l}\text { Depersonalization } \\
\text { (DE) }\end{array}$ & 155 & 7.22 & 6.00 & 2.00 & 6.00 & 11.50 & 0.00 & 24.00 & $<$. \\
\hline $\begin{array}{l}\text { Personal } \\
\text { Accomplishment (PA) }\end{array}$ & 147 & 29.07 & 8.43 & 23.00 & 29.00 & 35.00 & 8.00 & 48.00 & 0.322 \\
\hline \multicolumn{10}{|c|}{$\begin{array}{l}\text { Legend: } \mathrm{n} \text { - group quantity; } \mathrm{M} \text { - mean; SD - standard deviation; Q.25\% - first quartile; Me - median; } \\
\text { Q.75\% - third quartile; Min. - minimum; Max. - maximum; } p \text { - calculated level of significance for } \\
\text { standard test Shapiro-Wilk. *The figures in column } \mathrm{n} \text { do not sum up to } 161 \text { due to missing data. }\end{array}$} \\
\hline
\end{tabular}

\section{Significant Correlations}

We tested for relationships between various sociodemographic variables and the assessment of needs. Needs met was negatively correlated with both age $(p=0.011)$ and employment $(p=0.022)$ such that higher caregiver report of needs met was reported among younger and employed examinees. A lower rate of needs met was reported among care providers residing in urban areas as compared to those in rural ones $(p=0.007)$ (Table 4$)$. 
Table 4

Relationship between the variable sociodemographic data and the assessment of the met needs

\begin{tabular}{lll}
\hline Variable & \multicolumn{2}{l}{ Camberwell Index } \\
\cline { 2 - 3 } & $\mathbf{r}$ & $\mathbf{p}$ \\
\hline Gender & 0.10 & 0.197 \\
\hline Age (in years) & -0.20 & 0.011 \\
\hline Marital status & -0.06 & 0.482 \\
\hline Education & -0.01 & 0.877 \\
\hline Family-related caregiver & -0.08 & 0.330 \\
\hline Non-family caregiver & 0.27 & 0.339 \\
\hline Employment & -0.18 & 0.022 \\
\hline Place of residence (urban/rural) & 0.21 & 0.007
\end{tabular}

Legend: $p$ - level of significance for test verifying null hypothesis, that $r=0$ in contrary to $r \neq 0 ; r$ Spearman correlation coefficient; r-if $p \leq 0.05$.

Next, we tested for associations between sociodemographic variables and severity of burnout among care providers. We found that severity of burnout was positively associated age, marital status, and employment. Severity of burnout was negatively associated with education and place of residence. Lower results in EE and DE subscales were more frequently found in younger $(p=0.010 ; p=0.009)$, single or married ( $p=0.02 ; p=0.003)$ care providers than in older, widowed or divorced providers. Care providers residing in cities reported higher rates of $\operatorname{EE}(p=0.006)$ than those living in the country. Higher values of DE were observed among less educated $(p=0.028)$ care providers as compared to well-educated providers. Employed care providers showed lower rates of burnout on $\mathrm{DE}(p=0.005)$ and $\mathrm{EE}(p=0.018)$ subscales than unemployed providers (Table 5). 
Table 5

The relationship between variable sociodemographic data and the severity of burnout among care providers

\begin{tabular}{|c|c|c|c|c|c|c|}
\hline \multirow[t]{3}{*}{ Variable } & \multicolumn{2}{|l|}{ MBI } & \multicolumn{2}{|l|}{$\mathrm{MBI}$} & \multicolumn{2}{|l|}{ MBI } \\
\hline & \multicolumn{2}{|c|}{$\begin{array}{l}\text { Emotional } \\
\text { Exhaustion (EE) }\end{array}$} & \multicolumn{2}{|c|}{$\begin{array}{l}\text { Depersonalization } \\
\text { (DE) }\end{array}$} & \multicolumn{2}{|c|}{$\begin{array}{l}\text { Personal } \\
\text { Accomplishment (PA) }\end{array}$} \\
\hline & $\mathbf{r}$ & $\mathbf{p}$ & $\mathbf{r}$ & $\mathbf{p}$ & $\mathbf{r}$ & $\mathbf{p}$ \\
\hline Gender & -0.04 & 0.640 & 0.00 & 0.969 & -0.04 & 0.647 \\
\hline Age (in years) & 0.21 & 0.010 & 0.21 & 0.009 & -0.08 & 0.336 \\
\hline Marital status & 0.19 & 0.020 & 0.24 & 0.003 & -0.09 & 0.303 \\
\hline Education & -0.11 & 0.164 & -0.18 & 0.028 & 0.12 & 0.136 \\
\hline Family-related caregiver & -0.12 & 0.148 & -0.06 & 0.492 & -0.09 & 0.321 \\
\hline Non-family caregiver & -0.11 & 0.708 & -0.08 & 0.775 & -0.15 & 0.596 \\
\hline Employment & 0.19 & 0.018 & 0.23 & 0.005 & -0.09 & 0.264 \\
\hline $\begin{array}{l}\text { Place of residence } \\
\text { (urban/rural) }\end{array}$ & -0.22 & 0.006 & -0.11 & 0.184 & 0.15 & 0.062 \\
\hline
\end{tabular}

\section{Main Results}

We also tested for a potential between burnout and unmet needs among care providers. We found a significant relationship $(p<0.001)$ between unmet needs and burnout in the all three MBI subscales (i.e., EE, DE, PA; see Table 6).

Table 6

Analysis between subscales MBI of the unmet needs

\begin{tabular}{|lll|}
\hline Variable & \multicolumn{2}{l|}{ Unmet Needs } \\
\cline { 2 - 3 } & $\mathbf{r}$ & $\mathbf{p}$ \\
\hline $\mathrm{MBI}$ - Emotional Exhaustion (EE) & -0.47 & $p<0.001$ \\
\hline $\mathrm{MBI}$ - Depersonalization (DE) & -0.34 & $p<0.001$ \\
\hline $\mathrm{MBI}$ - Personal Accomplishment (PA) & 0.32 & $p<0.001$ \\
\hline $\begin{array}{l}\text { Legend: } p \text { - level of significance for test verifying null hypothesis, that } r=0 \text { in contrast to } r \neq 0 ; r- \\
\text { Spearman correlation coefficient; } r \text { - if } p \leq 0.05 .\end{array}$ & \\
\hline
\end{tabular}




\section{Method Of Logistic Regression}

The logistic regression performed in care providers of CVD patients was also significant for unmet needs (Table 7; odds ratios reported in Table 7a). 
Table 7

Results of logistic regression analysis in care providers. Explained variable: unmet needs (0-more unmet needs, 1 - fewer unmet needs)
Explanatory variables
bi
$\mathrm{SE}_{i}$
$\mathbf{z}_{\mathrm{i}}$
$p_{i}=\operatorname{Pr}\left(>\left|z_{i}\right|\right)$

Models with 2 explanatory variables

Model $1(n=161)$

$$
\mathrm{Chi}^{2}=9.66, \mathrm{df}=2, p=0.008, \text { pseudo } R^{2}=0.04
$$

Free term

$\begin{array}{lllllll}1 & \mathrm{X} 1 & \text { Gender } & 0.919 & 0.320 & 2.874 & 0.004 \\ 2 & \mathrm{X} 2 & \text { Age } & -0.023 & 0.008 & -2.980 & 0.003\end{array}$

Model $2(n=161)$

$\mathrm{Chi}^{2}=4.97, \mathrm{df}=2, p=0.083$, pseudo $R^{2}=0.02$

Free term

$\begin{array}{lllllll}1 & \mathrm{X} 1 & \text { Gender } & 0.506 & 0.242 & 2.085 & 0.037 \\ 2 & \mathrm{X} 3 & \text { Marital status } & -0.335 & 0.157 & -2.134 & 0.033\end{array}$

Models with 3 explanatory variables

Model $3(n=161)$

Chi $^{2}=11.15, \mathrm{df}=3, p=0.011$, pseudo $R^{2}=0.05$

Free term

$\begin{array}{lllllll}1 & \text { X4 } & \text { Place of residence } & 0.340 & 0.115 & 2.955 & 0.003 \\ 2 & \text { X5 } & \text { Education } & -0.117 & 0.059 & -1.978 & 0.048 \\ 3 & \text { X8 } & \text { Employment } & -0.161 & 0.063 & -2.559 & 0.011\end{array}$

Legend: Chi-squared - statistical hypothesis test of chi2 model adjustment; $\mathrm{df}$ - number of degrees of freedom; $p$-calculated level of test significance (if $p \leq 0.05$, model introduces relevant information as it differs significantly from free term model); pseudo $R^{2}$ - value which evaluates explanatory variable anticipation according to the model $\left(0 \leq\right.$ pseudo $R^{2}<1$, the bigger the value the better anticipation); $b i$ - coefficient estimation in regression model; SE $i$ - standard error estimation for $b i$ coefficient; $z i$ - value of test statistics in standard distribution; $(p i=\operatorname{Pr}(>|z|)$ - calculated probability value $p i$ for double-sided critical area equal to $z$ (if $p i \leq 0,05$, null hypothesis is rejected that $b i$ coefficient $=0$ which means that $i$-variable is relevant in the model); $n$-group quantity.

Table 7a presents the results of the odds ratio in logistic regression model for the risk of unmet needs occurrence among care providers. It was found that female care providers are 2.51 times more likely to experience unmet needs than male care providers. 
Younger care providers were 1.02 times less likely to report unmet needs than care providers who were a year older, and were 6.07 times less likely than 78 year-old providers.

Care providers with a rank in terms of marital status lower by 1 were 1.4 times less likely to report unmet needs than those with a higher category. In particular, single care providers were 2.73 times less likely to report unmet needs as compared to divorced care providers.

Care providers with a higher rank in terms of residence were 1.4 times less likely to report unmet needs as compared to those with a residence rank lower by 1 . In particular, rural residents were 2.77 times less likely to report unmet needs than those residing in big cities.

Care providers with a higher rank in terms of education were 1.12 times more likely to report unmet needs than those with a lower educational rank. In particular, care providers with primary education were 2.02 times less likely to report unmet needs than highly-educated providers.

Care providers with a lower rank in terms of employment were 1.17 times less likely to report unmet needs than those in employment categories higher by 1 . In particular, care providers who are employed full-time were 2.24 times less likely to report unmet needs than unemployed providers. 
Table 7

a. Odds ratio of logistic regression model in the group of care providers. Explained variable: unmet needs (0-more unmet needs, 1 - fewer unmet needs)

\begin{tabular}{|c|c|c|c|c|c|c|c|c|c|c|c|c|}
\hline \multicolumn{2}{|c|}{$\begin{array}{l}\text { Explanatory } \\
\text { variable }\end{array}$} & \multicolumn{5}{|c|}{ Per unit } & \multicolumn{6}{|c|}{ Per range } \\
\hline & & OR & \multicolumn{3}{|c|}{$95 \% \mathrm{Cl}$} & $1 / \mathrm{OR}$ & OR & \multicolumn{3}{|c|}{$95 \% \mathrm{Cl}$} & $1 / O R$ & range \\
\hline \multicolumn{13}{|c|}{ Model 1} \\
\hline $\mathrm{X} 1$ & $\begin{array}{l}\text { Gender (1- } \\
\text { 2) }\end{array}$ & 2.51 & 1.36 & - & 4.81 & 0.40 & 2.51 & 1.36 & - & 4.81 & 0.40 & 1 \\
\hline \multirow[t]{2}{*}{$\mathrm{X} 2$} & Age (17-95) & 0.98 & 0.96 & - & 0.99 & 1.02 & 0.16 & 0.05 & - & 0.52 & 6.07 & 78 \\
\hline & Model 2 & & & & & & & & & & & \\
\hline \multirow[t]{2}{*}{ X3 } & $\begin{array}{l}\text { Marital } \\
\text { status (1-4) }\end{array}$ & 0.72 & 0.52 & - & 0.98 & 1.40 & 0.37 & 0.14 & - & 0.90 & 2.73 & 3 \\
\hline & Model 3 & & & & & & & & & & & \\
\hline $\mathrm{X} 4$ & $\begin{array}{l}\text { Place of } \\
\text { residence } \\
(1-4)\end{array}$ & 1.40 & 1.13 & - & 1.77 & 0.71 & 2.77 & 1.43 & - & 5.56 & 0.36 & 3 \\
\hline X5 & $\begin{array}{l}\text { Education } \\
(1-7)\end{array}$ & 0.89 & 0.79 & - & 0.99 & 1.12 & 0.50 & 0.24 & - & 0.98 & 2.02 & 6 \\
\hline X8 & $\begin{array}{l}\text { Employment } \\
(1-6)\end{array}$ & 0.85 & 0.75 & - & 0.96 & 1.17 & 0.45 & 0.24 & - & 0.82 & 2.24 & 5 \\
\hline
\end{tabular}

The analysis of logistic regression in the group of care providers of CVD patients was also significant for EE (Table 8; odds ratios in Table 8a). 
Table 8

The odds ratio in logistic regression model in care providers. Explained variable: EE (0-smaller, 1- bigger $\mathrm{EE})$
Explanatory variables
$\mathrm{bi}$
$\mathrm{SE}_{i}$
$\mathbf{z}_{i}$
$\mathrm{p}_{i}=\operatorname{Pr}\left(>\mid z_{i}\right)$

Models with 2 explanatory variables

Model $1(n=154)$

$\mathrm{Chi}^{2}=8.51, \mathrm{df}=2, p=0.014$, pseudo $R^{2}=0.04$

\begin{tabular}{lllllll}
\multicolumn{2}{l}{ Free term } & & - & - & - & - \\
1 & $\mathrm{X} 2$ & Age & 0.015 & 0.006 & 2.607 & 0.009 \\
2 & $\mathrm{X} 4$ & Place of residence & -0.313 & 0.111 & -2.818 & 0.005
\end{tabular}

Model $2(n=154)$

$\mathrm{Chi}^{2}=5.29, \mathrm{df}=2, p=0.071$, pseudo $R^{2}=0.03$

Free term

1

2
Education

Employment
$-$

$-0.08$

0.106
$-$

0.044

0.052

2.045
$-$

0.046

0.041

Legend: Chi-squared - statistical hypothesis test of chi2 model adjustment; df - number of degrees of freedom; $p$ - calculated level of test significance (if $p \leq 0.05$, model introduces relevant information as it differs significantly from free term model); pseudo $R^{2}$ - value which evaluates explanatory variable anticipation according to the model $\left(0 \leq\right.$ pseudo $R^{2}<1$, the bigger the value the better anticipation); $b i$ - coefficient estimation in regression model; SE $i$ - standard error estimation for $b i$ coefficient; $z i$ - value of test statistics in standard distribution; $(p i=\operatorname{Pr}(>\mid z i)$ - calculated probability value $p i$ for double-sided critical area equal to $z$ (if $p i \leq 0,05$, null hypothesis is rejected that $b i$ coefficient $=0$ which means that $i$-variable is relevant in the model); $n$-group quantity.

Table 8a presents the results of the odds ratio in logistic regression model for the risk of EE occurrence among care providers of CVD patients. Older care providers were 1.02 times more likely to report EE occurrence than their younger counterparts, and were 3.32 times more likely to report EE than caregivers who were 78 years younger.

Care providers with a lower rank in terms of residence were 1.37 more likely to report EE than those with a higher residence category. In particular, urban residents were 2.56 times more likely to report EE than those living in the countryside.

Care providers who ranked lower rank in terms of education were 1.09 times more likely to report EE than those who ranked higher in terms of education. In particular, care providers with primary education were 1.69 times more likely to report EE than highly educated providers. 
Care providers with a higher rank in terms of employment were 1.11 times more likely to report EE than those who ranked lower in the employment category. In particular, care providers who are currently unemployed were 1.70 times more likely to report EE than full-time employees.

Table 8

a. The odds ratio in logistic regression model in care providers. Explained variable: EE (0-smaller, 1- bigger EE)

\begin{tabular}{|c|c|c|c|c|c|c|c|c|c|c|c|c|}
\hline \multicolumn{2}{|c|}{$\begin{array}{l}\text { Explanatory } \\
\text { variable }\end{array}$} & \multicolumn{5}{|c|}{ Per unit } & \multicolumn{6}{|c|}{ Per range } \\
\hline & & OR & $95 \% \mathrm{C}$ & & & $1 / \mathrm{OR}$ & OR & $95 \% \mathrm{C}$ & & & $1 / \mathrm{OR}$ & range \\
\hline \multicolumn{13}{|c|}{ Model 1} \\
\hline $\mathrm{X} 2$ & Age (17-95) & 1.02 & 1.00 & - & 1.03 & 0.98 & 3.32 & 1.37 & - & 8.41 & 0.30 & 78 \\
\hline \multirow[t]{2}{*}{$\mathrm{X} 4$} & $\begin{array}{l}\text { Place of } \\
\text { residence } \\
(1-4)\end{array}$ & 0.73 & 0.58 & - & 0.91 & 1.37 & 0.39 & 0.20 & - & 0.74 & 2.56 & 3 \\
\hline & Model 2 & & & & & & & & & & & \\
\hline$\times 5$ & $\begin{array}{l}\text { Education } \\
(1-7)\end{array}$ & 0.92 & 0.84 & - & 0.99 & 1.09 & 0.59 & 0.35 & - & 0.98 & 1.69 & 6 \\
\hline X8 & $\begin{array}{l}\text { Employment } \\
(1-6)\end{array}$ & 1.11 & 1.01 & - & 1.23 & 0.90 & 1.70 & 1.03 & - & 2.86 & 0.59 & 5 \\
\hline
\end{tabular}

Next, we analysed the logistic regression in the group of care providers of CVD patients for DE (Table 9; odds ratios reported in Table 9a). 
Table 9

The odds ratio in logistic regression model in care providers. Explained variable: DE (0-smaller, 1- bigger $\mathrm{DE})$
Explanatory variable
$\mathrm{bi}$
$\mathrm{SE}_{i}$
$\mathbf{z}_{i}$
$\mathrm{p}_{i}=\operatorname{Pr}\left(>\mid z_{i}\right)$

Models with 2 explanatory variables

Model $1(n=155)$

$\mathrm{Chi}^{2}=8.20, \mathrm{df}=2, \mathrm{p}=0.017$, pseudo $R^{2}=0.05$

\begin{tabular}{lllllll}
\multicolumn{2}{c}{ Free term } & & - & - & - & - \\
1 & $\mathrm{X} 4$ & Place of residence & -0.190 & 0.071 & -2.664 & 0.008 \\
2 & X9 & Period of homecare & 0.041 & 0.021 & 1.965 & 0.049
\end{tabular}

Model $2(n=155)$

$\mathrm{Chi}^{2}=8.58, \mathrm{df}=2, \mathrm{p}=0.014$, pseudo $R^{2}=0.05$

Free term

$1 \quad \times 5$

$2 \quad x 9$

Period of homecare
$-0.127$

0.043
0.047

0.022
$-2.701$

1.982
$-$

0.007

0.047

Legend: Chi-squared - statistical hypothesis test of chi2 model adjustment; df - number of degrees of freedom; $\mathrm{p}$ - calculated level of test significance (if $p \leq 0.05$, model introduces relevant information as it differs significantly from free term model); pseudo $R^{2}$ - value which evaluates explanatory variable anticipation according to the model $\left(0 \leq\right.$ pseudo $R^{2}<1$, the bigger the value the better anticipation); $b i$ - coefficient estimation in regression model; SE $i$ - standard error estimation for $b i$ coefficient; $z i$ - value of test statistics in standard distribution; $(p i=\operatorname{Pr}(>\mid z i)$ - calculated probability value $p i$ for double-sided critical area equal to $z$ (if $p i \leq 0,05$, null hypothesis is rejected that $b i$ coefficient $=0$ which means that $i$-variable is relevant in the model); $n$-group quantity.

Table 9a presents the results of the odds ratio in the logistic regression model for the risk of DE occurrence among care providers of CVD patients.

Care providers who ranked lower in terms of residence were 1.21 times more likely to report DE than those who ranked higher in the residence category. In particular, care providers residing in cities were 1.77 times more likely to report DE than those living in the countryside.

Care providers who worked for a longer period of time were 1.04 times more likely to report DE than those who provided care for a shorter period of time. Further, care providers who provided 50 more years of care were 7.84 times more likely to report DE than those who provided care for shorter periods.

Care providers who ranked lower in terms of education were 1.14 times more likely to report DE than those who ranked higher in the education category. In particular, care providers with primary education were 2.15 times more likely to report DE than highly educated providers. 
Table 9

a. The odds ratio in logistic regression model in care providers. Explained variable: DE (0-smaller, 1- bigger $\mathrm{DE})$

\begin{tabular}{|c|c|c|c|c|c|c|c|c|c|c|c|c|}
\hline \multicolumn{2}{|c|}{$\begin{array}{l}\text { Explanatory } \\
\text { variable }\end{array}$} & \multicolumn{5}{|c|}{ Per unit } & \multicolumn{6}{|c|}{ Per range } \\
\hline & & OR & $95 \% \mathrm{C}$ & & & $1 / O R$ & OR & $95 \% \mathrm{C}$ & & & $1 / \mathrm{OR}$ & range \\
\hline \multicolumn{13}{|c|}{ Model 1} \\
\hline$X 4$ & $\begin{array}{l}\text { Place of } \\
\text { residence } \\
(1-4)\end{array}$ & 0.83 & 0.72 & - & 0.95 & 1.21 & 0.57 & 0.37 & - & 0.85 & 1.77 & 3 \\
\hline$\times 9$ & $\begin{array}{l}\text { Period of } \\
\text { homecare } \\
(1-51)\end{array}$ & 1.04 & 1.00 & - & 1.09 & 0.96 & 7.84 & 1.19 & - & 79.55 & 0.13 & 50 \\
\hline \multicolumn{13}{|c|}{ Model 2} \\
\hline$\times 5$ & $\begin{array}{l}\text { Education } \\
(1-7)\end{array}$ & 0.88 & 0.80 & - & 0.96 & 1.14 & 0.47 & 0.26 & - & 0.80 & 2.15 & 6 \\
\hline
\end{tabular}

Next, we evaluated results of the logistic regression in the group of care providers of CVD patients for decreased level of PA variable (Table 10; odds ratios reported in Table 10a).

Table 10

The odds ratio in logistic regression model in care providers. Explained variable: PA (0-smaller, 1- bigger PA)

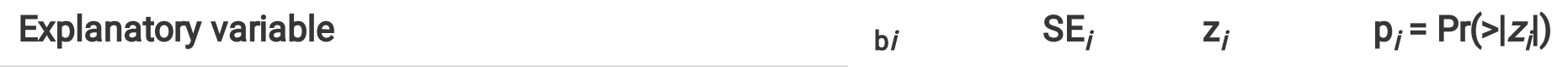

\section{Models with 2 explanatory variables}

Model $1(n=147)$

$$
\mathrm{Chi}^{2}=6.05, \mathrm{df}=2, p=0.049, \text { pseudo } R^{2}=0.03
$$

\begin{tabular}{lllllll}
\multicolumn{2}{l}{ Free term } & & - & - & - & - \\
1 & $\mathrm{X} 1$ & Gender & 0.616 & 0.258 & 2.390 & 0.017 \\
2 & $\mathrm{X} 4$ & Place of residence & -0.246 & 0.116 & -2.113 & 0.035
\end{tabular}

Legend: Chi-squared - statistical hypothesis test of chi2 model adjustment; df - number of degrees of freedom; $p$-calculated level of test significance (if $p \leq 0.05$, model introduces relevant information as it differs significantly from free term model); pseudo $R^{2}$ - value which evaluates explanatory variable anticipation according to the model $\left(0 \leq\right.$ pseudo $R^{2}<1$, the bigger the value the better anticipation); $b i$ - coefficient estimation in regression model; SE $i$ - standard error estimation for $b i$ coefficient; $z i$ - value of test statistics in standard distribution; $(p i=\operatorname{Pr}(>|z|)$ - calculated probability value $p i$ for double-sided critical area equal to $z$ (if $p i \leq 0,05$, null hypothesis is rejected that $b i$ coefficient $=0$ which means that $i$-variable is relevant in the model); $n$-group quantity. 
Table 10a presents the results of the odds ratio in the logistic regression model for the risk of PA occurrence among care providers of CVD patients.

We found that females were 1.85 times more likely to report a decrease in PA than their male counterparts.

Care providers who ranked lower in terms of residence were 1.28 times more likely to report a decrease in PA than those who ranked higher in this category. In particular, residents of big cities were 2.09 times more likely to report a decrease in PA than residing in the countryside.

Table 10

a. The odds ratio in logistic regression model in care providers. Explained variable: PA (0-smaller, 1-bigger PA)

\begin{tabular}{|c|c|c|c|c|c|c|c|c|c|c|c|c|}
\hline \multicolumn{2}{|c|}{$\begin{array}{l}\text { Explanatory } \\
\text { variable }\end{array}$} & \multicolumn{5}{|c|}{ Per unit } & \multicolumn{6}{|c|}{ Per range } \\
\hline & & OR & $95 \%$ & & & $1 / \mathrm{OR}$ & OR & $95 \%$ & & & $1 / \mathrm{OR}$ & range \\
\hline \multicolumn{13}{|c|}{ Model 1} \\
\hline $\mathrm{X} 1$ & $\begin{array}{l}\text { Gender (1- } \\
\text { 2) }\end{array}$ & 1.85 & 1.13 & - & 3.12 & 0.54 & 1.85 & 1.13 & - & 3.12 & 0.54 & 1 \\
\hline $\mathrm{X} 4$ & $\begin{array}{l}\text { Place of } \\
\text { residence } \\
(1-4)\end{array}$ & 0.78 & 0.62 & - & 0.98 & 1.28 & 0.48 & 0.24 & - & 0.94 & 2.09 & 3 \\
\hline
\end{tabular}

\section{Discussion}

In our data, we found that $70.2 \%$ of all care providers are women. This finding is similar to results of a prior study of care providers of the elderly (74.8\% women) [20], and in another study on care providers from the chronically ill conducted by Marzec et al. (68.56\% women) [21]. Together, these data suggest that there is a link between sex and care providing. In most cases, we found that care providers were over the age of 55 , married, residing in urban areas, and were related to the patient (i.e., parents or spouses).

The present study showed that older, unemployed care providers who reside in urban areas were more likely to report unmet needs. We also demonstrated that female, older, divorced, well-educated, and unemployed care providers who live in urban areas were more likely to report unmet needs. The literature on the subject lacks research on the assessment of needs met (or unmet) by informal carers of people with CVD. Care should be taken in interpreting the results due to the small size of the research group. It seems, however, that these results are a good contribution to further research in this field, and identify people with specific characteristics that should be the target of programs to improve care for carers for people with CVD. 
In our study, the severity of burnout in caregivers showed to be at an average level. The highest results were found in the subscale that involved a sense of lack of personal accomplishments. Similar results were obtained when examining the burnout of family members in the care of a cancer patient covered by palliative home care [22].

In the present study, advanced age, marital status (i.e., divorced or widowed) and unemployment were related to higher reports of $E E$ and $D E$, whereas a lower level of education was associated with higher reports of DE. In addition, DE was more likely to be reported among older, unemployed, and less educated care providers who reside in big cities. Higher DE was reported among less educated city residents who have been providing care for a longer period of time. Decreased PA, in contrast, was more likely to be reported among female care providers and those living in the countryside.

Additionally, the present study discovered a significant $(p<0.001)$ relationship between unmet needs and burnout, as measured by the MBI. This association was significant with for all three MBI subscales (i.e., $\mathrm{EE}, \mathrm{DE}$ and $\mathrm{PA}$ ). Due to the lack of research in the subject literature, our results suggest the need for more research on unmet needs of care providers of CVD patients to develop support services and adopt suitable interventions.

The findings of our study have revealed that there is a need for the comprehensive recognition of the needs of informal carers. If carers have unmet needs, this affects their health and well-being, which can make it difficult for them to provide effective care in the way they want. It is therefore important to determine how carer needs are, or are not being met. A study showed that $35 \%$ of support persons (i.e. informal caregivers) had at least one unmet need. Among this group, almost two-thirds reported many unmet needs (64.7\%) [23]. Another study found that informal caregivers reported almost twice as many needs as the patients they care for [24]. Comprehensive identification of needs enables problem identification and adequate intervention that can eliminate or reduce the need. Assessment of the degree to which caregivers' needs are met is therefore crucial in addressing growing levels of biopsychosocial disorders.

Research on environmental systems of social support and care for the elderly showed that informal care providers most frequently report issues such as lack of time for care, and the need for institutional and personal support [20]. Further, prior research demonstrates that care providers require information and training (e.g., first aid in emergency situations, practical advice on bedridden patient care, simple medical procedures, administering drugs, patting to prevent bedsores, providing basic massages and rehabilitation procedures, measuring blood pressure, among others), as well as, counselling and the availability of substitute care $[8,12]$. Another key issue is communication between health service workers and care providers. Care providers typically feel powerless and ignored if they fail to establish a relationship with medical professionals. This lack of coordination between health care providers, as well as a lack of access to information has been clearly highlighted in studies and in consultation with interested parties [8]. 
The care of chronically ill patients evokes long-term stress and can in turn, lead to tremendous burden among care providers. In the scientific literature, it is difficult to find a clear definition of burden in evaluating the work of informal caregivers. The term 'burden' is usually related to a multi problem situation that tends to persist over time. Burden is frequently associated with stress, which can lead to emotional, mental, and physical exhaustion of a caregiver [25]. The results in this study demonstrating the relationship between sociodemographic data of informal caregivers and the severity of burnout, provide the basis for more in-depth study and interest in these issues, and testify to the high demand for professional support (e.g., helpline, psychological counselling, support groups) to reduce the psychological burden on caregivers.

It is important to note that it is the first study in Poland to report a relationship between sociodemographic factors and the needs and severity of burnout among informal care providers of CVD patients. The results presented here might be useful for creating systems of support for individuals and families who are seeking assistance in nursing patients who are not self-reliant. These data may also help to inform the creation of care quality evaluation tools with the analysis of its needs and expectations in somatic, mental, social, and environmental aspects. Such examinations might improve quality of life among care providers, by helping them to manage their own needs, as well as, their mental and physical wellbeing.

\section{Limitations}

One limitation of the present study is the relatively limited sample size, which limits our ability to generalize the results to the entire whole population of informal care providers of CVD patients in Poland. This may be apparent in the relatively low values of the pseudo $R^{2}$ indicator, which assesses the prediction of an explained variable with the use of a model. Here, the calculated pseudo $R^{2}$ values ranged from 0.02 to $0.05\left(0 \leq\right.$ pseudo $\left.R^{2}<1\right)$, where the higher the value, the better the prediction. Nonetheless, results of the present study are valuable and might be used in the course of interventions that support the development of a systemic model of home care for chronically ill patients. Future research should include a greater number of respondents and health care institutions.

\section{Conclusions}

Advanced age, sex, marital status, unemployment, place of residence, and high education of care providers was related to a decreased level of needs met among providers. Care providers with the aforementioned characteristics should be targeted with programmes that aim to determine the category of unmet needs and provide tailor-made support in the relevant needs categories. Older, less educated, and unemployed care providers who have been providing care for a longer period of time and reside in cities or in the countryside should be included in burnout prevention programmes. Fulfilling unmet needs in care providers is important not only for planning supportive services, but also because there is a straightforward relationship between unmet needs and the exacerbation of $E E, D E$, and decreased PA.

\section{Abbreviations}


$\mathrm{MBI}$

Maslach Burnout Inventory

EE

Emotional exhaustion

DE

Depersonalization

PA

Personal accomplishment

\section{Declarations}

\section{Ethics approval and consent to participate}

The study was approved by the Bioethical Commission at Medical University in Wroclaw (No KB -86/2016). Participation in the study was voluntary and anonymous. All participants were informed about the study aims, methods, and the possibility of study withdrawal at any stage and gave oral consent to participate in the study. The Bioethical Commission approved the procedure for obtaining oral consent from study participants, because the study only used anonymous surveys.

\section{Consent for publication}

Not applicable in this section.

\section{Availability of data and materials}

The datasets used and/or analysed during the current study are available from the corresponding author on reasonable request.

\section{Competing interests}

The authors declare that they have no competing interests. Co-author Donata Kurpas is an Associate Editor of this journal.

\section{Funding}

Research financed by the author ESC.

\section{Author's contributions}

ESC contributed to preparation of the study design, collection of data, statistical analysis, data interpretation, creation of final version of the article, and literature review. MG, DEB, At, PP contributed to basic data collection. DK contributed to preparation of the study design, data interpretation, and preparation of the final manuscript. All authors read and approved the final version of the manuscript. 
Acknowledgements

The authors would like to thank you Artur Prusaczyk, MD (the CEO of Medical and Diagnostic Centre (MDC), Siedlce, Poland) for the cooperation during data collecting.

\section{Authors email:}

Marika Guzek - marika.guzek@centrum.med.pl

Dorota Emilia Bielska - d.bielska1@wp.pl

Anna Ławnik - lawnikania@gmail.com

Piotr Polański - p.polanski@wp.pl

Donata Kurpas - dkurpas@hotmail.com

\section{References}

1. Narodowy Instytut Zdrowia Publicznego - PZH. Red. Wojtyniak B, Goryński P. Sytuacja zdrowotna ludności Polski i jej uwarunkowania. Warszawa 2016. http://www.pzh.gov.pl/stan-zdrowialudnosci/sytuacja-zdrowotna-ludnosci-w-polsce/. Accessed 22 June 2019.

2. Nichols M, Townsend N, Peter Scarborough P, Rayner M. Cardiovascular disease in Europe 2014: epidemiological update. Eur Heart J.2014;35(42):2950-2959. https://www.ncbi.nlm.nih.gov/pubmed/25139896

3. Muszalik M, Kędziora-Kornatowska K. Jakość życia przewlekle chorych pacjentów w starszym wieku. Gerontol Pol. 2006;14(4):85-189.

4. Nanette K. Wenger NK - The greying of cardiology: implications for management. Heart. 2007;93(4):411-412.

5. GUS. Sytuacja demograficzna osób starszych i konsekwencje starzenia się ludności Polski w świetle prognozy na lata 2014-2050. http://stat.gov.pl/obszary-tematyczne/ludnosc/ludnosc/sytuacjademograficzna-osob-starszych-i-konsekwencje-starzenia-sie-ludnosci-polski-w-swietle-prognozy-nalata-2014-2050,18,1.html. Accessed 22 June 2019.

6. McNamara B, Rosenwax L. Which carers of family members at the end of life need more support from health services and why? Soc Sci Med. 2010;70(7):1035-1041.

7. Galiatsatos P, Gurley A, Daniel Hale W. Policy and advocacy for informal caregivers: How state policy influenced a community initiative. J Public Health Policy. 2017;38(4):503-508. https://doi.org/10.1057/s41271-017-0084-x.

8. Morris SM, King C, Turner M, et al. Family carers providing support to a person dying in the home setting: A narrative literature review. Palliat Med. 2015;29(6):487-495. 
9. Rosochacka-Gmitrzak M. Starzenie się w miejscu zamieszkania a zakłócony performance miejsca. Miscellanea Anthropologica et Sociologica. 2018;19(4):33-52.

10. GUS. Zdrowie i zachowanie zdrowotne mieszkańców Polski w świetle Europejskiego Ankietowego Badania Zdrowia (EHIS) 2014 r. Warszawa 2015. https://stat.gov.pl/obszarytematyczne/zdrowie/zdrowie/zdrowie-i-zachowania-zdrowotne-mieszkancow-polski-w-swietlebadania-ehis-2014,10,1.html Accesed 20 June 2019.

11. Ploeg J, Matthew-Maich N, Fraser K, Dufour S, et al. Managing multiple chronic conditions in the community: a Canadian qualitative study of the experiences of older adults, family caregivers and healthcare providers. BMC Geriatr. 2017;17(1):40.

12. Janowicz A. Rola opiekunów nieformalnych w opiece u kresu życia. Przyczynek do badań w ramach projektu European Palliative Care Academy (EUPCA). Piel Zdr Publ. 2014;4(2):161-167.

13. Duggleby W, Williams $A$, Ghosh $S$, Moquin $H$, et al. Factors influencing changes in health related quality of life of caregivers of persons with multiple chronic conditions. Health Qual Life Outcomes. 2016;14(1):81.

14. Madara Marasinghe K. Assistive technologies in reducing caregiver burden among informal caregivers of older adults: a systematic review. Disabil Rehabil Assist Technol. 2016;11(5):353-60. https://doi.org/10.3109/17483107.2015.1087061.

15. O'Brien MR, Whitehead B, Jack BA, et al. The need for support services for family carers of people with motor neurone disease (MND): views of current and former family caregivers a qualitative study. Disabil Rehabil. 2012;34(3):247-256.

16. Morais HC, Soares AM, Oliveira AR, et al. Burden and modifications in life from the perspective of caregivers for patients after stroke. Rev Lat Am Enfermagem. 2012;20(5):944-953.

17. Kurpas D. Paradygmat opieki nad chorymi przewlekle w ramach podstawowej opieki zdrowotnej. Uniwersytet Medyczny im. Piastów Śl. Wrocław 2013;61-62.

18. Pasikowski T.: Polska adaptacja kwestionariusza Maslach Burnout Inventory. W.: Sęk H. [red.]. Wypalenie zawodowe. Przyczyny i zapobieganie. Wydawnictwo Naukowe PWN, Warszawa. 2009;135-149.

19. Nitka-Siemińska A, Myśliwiec M, Landowski J, et al. Zespół wypalenia u rodziców osób chorych na cukrzycę typu 1. Diabetol Prakt. 2008;9(2):76-81.

20. Czub K, Szpyrka S, Zaręba M. Obserwatorium Integracji Społecznej. Wielkopolskie Regionalne Obserwatorium Terytorialne. Departament Polityki Regionalnej UMWW. Pogłębione studium usług opiekuńczych skierowanych do osób starszych. Środowiskowa opieka formalna i nieformalna. Raport z badań. Poznań 2017. https://rops.poznan.pl/wpcontent/uploads/2018/06/raport_Pogłębione-studium-usług-opiekuńczych-skierowanych-do-osóbstarszych.-Środowiskowa-opieka-formalna-i-nieformalna_wersja-końcowa.pdf. Accessed 22 June 2019.

21. Marzec A, Faleńczyk F, Pluta A, et al. Obciążenie opieką i depresyjność opiekuna osoby przewlekle chorej w domu, rodzaje problemów i czynniki wpływające na ich występowanie. Przeds Zarz. 
2013;14(10):243-258.

22. Gawlik M, Kurpas D. Ocena poziomu wypalenia członków rodzin w opiece nad pacjentem z chorobą nowotworową objętych domową opieką paliatywną. Fam Med Prim Care Re, 2014;16,4:336-340.

23. Temple JB, Dow B. The unmet support needs of carers of older Australians: prevalence and mental health. Int Psychogeriatr. 2018;30(12):1849-1860.

24. Kerpershoek L, de Vugt M, Wolfs C, Woods W, Martin Orrell M, et al. Needs and quality of life of people with middle-stage dementia and their family carers from the European Actifcare study. When informal care alone may not suffice. Aging Ment Health. 2018;22(7):897-902. https://doi.org/10.1080/13607863.2017.1390732.

25. Skrzypek-Czerko M, Kozera G, Chwojnicki K, et al. Znaczenie wsparcia społecznego dla poziomu lęku i depresji oraz obciążenia opiekunów pacjentów po udarze mózgu - wyniki wstępne. Pielęgn Neurol Neurochir. 2013;2(1):18-26. 